\title{
In Search of a NeW Epistemology of the Urban IN THE WRITING OF IVAN VLADISLAVIĆ
}

\begin{abstract}
This article looks at Ivan Vladislavić's literary explorations of the urban in post-apartheid South Africa, notably those concentrating on and around the city of Johannesburg, drawing examples from The Restless Supermarket (2001), Portrait with Keys: the City of Johannesburg Unlocked (2006), and The Exploded View (2004). Reading Vladislavić, the article traces the writer's involvement with categories, methods and cartographies through which urbanity and urban life after apartheid could be addressed and understood.

A point of departure for the discussion is the epistemological crisis of the late 1960 s and early 1970s, which challenged the positivist policy in urban research, thereby destabilising the intellectual foundations of urban as well as literary studies concentrating on urbanism. The analysis, recognising the inadequacy of the earlier categories related to the concept of the bounded city, concentrates on a search for new ways of knowing and investigating the increasingly complex urbanity.
\end{abstract}

\section{Keywords}

Ivan Vladislavić; Johannesburg; concept city; New Literatures in English; planetary urbanism $(P U)^{1}$

\section{Introduction}

An editor and author of both fiction and nonfiction, Ivan Vladislavić has been noticeably interested in architecture and urban development in South Africa. The writer reflects upon social and political reconfigurations by addressing the urban question. In an interview with Matt Seidel (Online), Vladislavić comments on his experience gathered from editing projects in urban development as well as 
exhibition catalogues, for example for blank Architecture, apartheid and after, which enabled him to become acquainted with architects and theorists debating the future of South African urbanism after the fall of apartheid. It is here, in blank Architecture, apartheid and after, that the cycle "Street addresses, Johannesburg", one of the itineraries in Portrait with Keys, was first published in 1998. In contrast with totalising city portraits and cityscapes, Vladislavić's interest in urban subjects often involves detailed and puzzling aspects of infrastructure, including areas most writers ignore, like sanitation. "Afritude Sauce", the second part of The Exploded View, devotes several pages to (non)-water-borne sanitary disposal and the dream of having a toilet seat at home, "a throne at the end of the passage" (Vladislavić 2004: 54), ${ }^{3}$ rather than "a hole in the ground" (Vladislavić 2004: 54). A proper sanitary installation becomes a status symbol, while its malfunctioning or the inability to cover its maintenance costs, are seen as a symptom of exclusion, a source of disappointment and a reason for politically flavoured complaint (Vladislavić 2004: 62-64). Commenting humorously, satirically, ironically and sometimes nostalgically on the changes taking place in post-apartheid South Africa, Vladislavić's writing converges around Johannesburg. It reveals a dynamic correspondence or, rather, an interaction between socio-political transformations and diverse urban developments - processes resulting in a hybridity that discovers in the cityscape of Johannesburg remnants of a European-style city (in Portrait with Keys), more suburban and Americanesque extensions (as in The Exploded View) and, as Sarah Nuttal and Achille Mbembe propose, original "Afropolitan" forms, a unique "entanglement of the modern and the African" (2007: 282), the Afropolitan bustle whose presence pervades several of Vladislavić's texts, for example The Restless Supermarket and Portrait with Keys.

In the following discussion I assume that, in the background of Vladislavić's writing, it is possible to trace a tangible adherence to the views of urban theoreticians and philosophers. Moreover, this adherence appears to relate, even if unintentionally, to political debates involving more recent directions in urban theory and practice and, implicitly rather than explicitly, to their epistemological potential. Urban concepts are constructs which have cognitive value and provide instruments for understanding the effects of socio-political transformations. Vladislavić does not target professional discussions, but we may notice the extent to which the writer is aware of the meaning and consequences of such urban concepts as gated communities, commonality, RDP or informal settlement. Considering the writer's editorial experience and aesthetic interests, it is reasonable to assume a certain degree of expertise even if he remains an amateur in urban studies. His intellectual inspirations are signalled distinctly by the visual and verbal peritexts surrounding his publications, the liminal zone bringing in contact the reader (with the extratextual) and the main body of the text. The covers of subsequent editions of Vladislavić's writing are carefully and meaningfully designed to foreground and metaphorically grasp the social and urban processes the texts address. Moreover, Portrait with Keys and The Restless Supermarket use epigraphs which point to changing ways of constructing and understanding urban space. 
Point A in Portrait with Keys: The City of Johannesburg Unlocked signals the nature of the correlation between urban theory and literary practise when the book opens the series of vignettes and itineraries with an epigraph authored by Michel de Certeau, the propagator of a peripatetic concept of knowing the city, an idea which transforms the text into a collection of "thematic pathways" reflecting the ways Johannesburg can or should be experienced. However, Vladislavić is precise in articulating his concepts and it is important to notice that the quotation selected by the epigrapher does not refer to de Certeau's well-known opposition between the embodied walker and the disembodied spectating voyeur. Instead, the epigraph draws the reader's attention to a significant reversal in the socially recognised importance of places, "Haunted places are the only ones people can live in" (1988: 108), thus revealing the rise of a new sense of commonality in post-apartheid times. Haunted places are hybrid and impure admitting the other, the revenant in the figures of beggars, sellers and ghouls. In Portrait Vladslavić employs the three essential functions of the epigraph indicated by Gerard Genette in Paratexts (1997). Epigraphs comment on and elucidate the often puzzling titles (Genette 156); indirectly specify the meaning of the text, which the reader may realise when the book is read (157) and, finally, the epigrapher's name can become a key to the understanding of the whole text (159). In the last case the epigraph functions more as an in memoriam or a dedication to the epigrapher, Michel de Certeau, whose key-proposition is still valid though likely to soon be replaced by new concepts the destabilised reality demands. The Restless Supermarket, with the fictitious epigraphed named Aubrey Tearle, and followed by William Hazlitt (the romantic poet) in the next epigraph, struggles to integrate the text via epigraphs. In the course of what Genette defines as the epigrapheffect, and its fourth basic function (160), the peritextual frame integrates the text into the philosophical tradition of writing the city in terms of totalising concepts. Here, as opposed to the Portrait, Vladislavić produces tension between the romantic tradition and the utopian city-state concepts on the one hand and the cityscape affected by disintegrating apartheid on the other. It is via epigraphs, with their prefatorial function, that the reader is introduced to the main text with its focus on the urban as a key term to be used in his hermeneutic pursuits. The extended peritextual zone foregrounds reader participation in the cultural practice of knowing the urban.

The message conveyed by the verbal peritexts is often complemented by the visual, notably by the covers with their puzzling images of urbanity. The aim of invoking de Certeau in the verbal peritext is complex. It foregrounds the underlying cognitive method of knowing the urban through an accretion of piecemeal, unfocused experiences of everydayness but, further on, its aim is to signal the layered nature of Johannesburg's urbanity with its accumulation of past experience. A visual equivalent of this layering is provided by the technique of palimpsest writing or drawing that reveals diverse, previously hidden facets of the city and signals change. Nuttal and Mbembe note that it is the "subliminal memory of life below the surface, of suffering, alienation [...] and insurrection - 
the powerful forces contained in the depths of the city" (2007: 287) whose presence is advertised by the cover image designed by William Kentridge, a South African artist and theatre maker. Nuttal and Mbembe are referring to the 2017 Archipelago edition of The Exploded View. The cover reveals an image conflating a human figure and a cracked tree trunk, presumably "a tree of gestures" (de Certeau 102), a ghostly image striding across the landscape. Studying the shape, the viewer is confused, trying to decide about backgrounds and foregrounds. Further away, in what is supposedly the background, the viewer discovers either a map or a clouded sky touching the skyline of a distant settlement. The palimpsest-like, imperfect erasure technique of animating drawings used by Kentridge produces shifting images in whose 'imperfections' we discover further objects, experiencing in that way a gnawing sense of uncertainty about compositional hierarchies and relations. Shane Graham argues that the cover renders the "continual inscription and effacement of social relations" (2006: 53) onto the physical landscape of Johannesburg. It looks as if the original 'manuscript', or image, has been erased and overwritten or painted over several times, so that what the viewer or reader is likely to experience is a sense of ungraspable instability and an invitation to co-create in the course of hermeneutic investigation. This ancient technique used in contemporary art marks a shift away from "black-boxing", ${ }^{4}$ a term denoting a change of attitude which points to the demise of universalising and condoning city images, such as concept cities. Moreover, it is indicative of a need for strategies of representation capable of identifying the so far invisible micro-worlds of urban life with their multifarious relations and secret signs such as the puzzling tomasons (PK 174). In The Exploded View, the hidden to be revealed is the infrastructure that comes to the fore while it is normally expected to be absorbed into the background and remain invisible, i.e. "black-boxed". Vladislavić's consistency in the message he intends to convey in peritexts shows in the earlier, 2004 Random House edition which uses a detail from Mary Wafer's painting, entitled Bridge - also depicting an element of infrastructure.

The peritextual frames complementing The Restless Supermarket, Portrait with Keys: the City of Johannesburg Unlocked, and The Exploded View foreground significantly the interest in urbanity indicating that its function transcends that of a traditional setting, a representation of the city or a painted backdrop. In the following discussion, examining the complex presence of the urban in Vladislavić's writing and inspired by the controversial but stimulating processoriented proposal put forward by Neil Brenner and Christian Schmid, the article explores changes in understanding the urban. Brenner and Schmid's proposal promises to go beyond modernist spatial concepts, data-oriented empiricism and politically-charged postcolonial studies with the binary of centres and margins - concepts used in the sense in which they function in urban research. In their manifesto-like essay entitled "Towards a new epistemology of the urban?" (2015), the two critical urban theorists ${ }^{5}$ argue for the need of a globally applicable theory and epistemology in order to reflect on urban restructuring whose beginning they locate in the1980s. The two theorists reject practice-oriented concepts, 
finding a further expansion of empiricism in urban research a cul de sac, i.e. they express a sceptical attitude to what is called empirical research and is associated with emphasis on collecting data, especially topographic surveys. Indeed, when criticized, empiricism is often affiliated either with a refusal to reveal its theoretical underpinnings or with an excessive focus on materiality collected with the aid of methods which should be replaced by remote sensing technologies in order to comment on the dynamics of transformations. As opposed to a thus formulated empirical approach, Brenner and Schmid, like men of letters and philosophers, theorize and textualize the urbanity. In response to their challenging concepts, practical urban studies have retaliated by observing that the academic prose of the new urban theorists offers imprecise guidelines, whose cause is "errant" though noble, while their proposal addresses mainly intellectuals (Walker 2015: 183184). Indeed, Schmid and Brenner's essay does address intellectuals rather than practitioners but functions, perhaps therefore, as an inspiring future-oriented eyeopener. Analogously, neither de Certeau nor Henri Lefebvre were practitioners. Hence, unsurprisingly, Schmid and Brenner go back to the crisis of the late 1960s to productively reappropriate the anticipatory hypothesis of "complete urbanisation" urged by Lefebvre in the 1970s (2003: 4, 86). Calling upon earlier conceptualisations, the aim of the subsequent enquiry is to trace and explore a correlation between the more recently reappropriated urban concepts, challenging the long-entrenched assumptions regarding the nature of the urban (Brenner 2014; Brenner and Schmid 2015), with its epistemological potential, and to relate these concepts to Vladislavić's urban writing, notably to his pursuit after an imaginary cultural practice shaping our understanding of urban environments.

\section{From city-centred to process-oriented approaches}

In the1960s and early 1970s, when Lefebvre spoke on the urban revolution, the debates centred mainly on the need for appropriate "categories and methods" (Brenner and Schmid 2015: 154) through which the changing urban world could be understood. The same dilemma underwrites the conurbations Vladislavić mentions years later in $R S$, calling them ungraspable, "lawless" and "unconnected"(30). As opposed to the present situation in urban studies, in the 1960s the crisis was diagnosed as purely epistemological. The contours of the urban, even in its upscale variants (e.g., agglomerations), were still perceived as forming definite spatial units and therefore always a "settlement type". As opposed to the 1960s, especially in view of planetary urbanism, the once fundamental concept of the bounded city has been relativised, if not superseded, crosscutting the traditional urban/ non-urban divide. These new developments in urban research remain, to some extent, in agreement with what Lefebvre wrote in 1970 expressing the belief that "the urban [...] slowly occupies an epistemological field, and becomes the episteme of an epoch", while the notion of "urbanism" remains hard to define (Lefebvre 2003: 191). In other words, we inhabit the world as urbanites 
or urban dwellers rather than country wenches and thus our cognitive activity sets out from the dynamically evolving urban perspective which is no longer stable. Planetary urbanism, assuming that the urban is no longer "anchored to the city" (Brenner and Schmid 2015: 159) and putting emphasis on the concept of "urbanism" as process, questions the validity of the categories and methods used so far. It enquires after a new theory and a new epistemology that might be useful for the understanding of the emergent field of research. In his writing, Vladislavić appears to be aware of these transformations. Even if he is not a conscious follower of the planetary urbanism proposed by Brenner and Schmid, he actively enquires after process-oriented categories dismantling the former spatial concepts. Notably in $R S, E V$ and $P K$, the city is mobilised: understanding the city via stable concepts belongs to the apartheid past.

Still, literary, comparative and interdisciplinary analysis often relies on spatial concepts and tends to regard the urban in urban writing, also called the literature of the city, as a "fixed, bounded and universally generalisable settlement type" (Brenner and Schmid 2015: 151), a morphologically singular category called the city whose scalar variants - town, city, metropolis, megapolis, agglomeration or a particular city, as in London literature - repeat essential morphological patterns. Indeed, the urban model called concept city boasts a tradition traceable to the mid sixteenth century, where scientifically constructed city portraits assumed cartographic, geographical or chorographic forms as well as that of views, panoramas and descriptions (Maier 2015: 3-4). Ideogrammatic city views and cities of the mind are anchored in earlier times, for example Fra Paolino Veneto's fourteenthcentury plan of Rome or Plato's Republic. City-centred, often place-based and binary-oriented explorations, have dominated the mainstream field of urban studies and their adaptations for cultural and literary research. This applies to numerous classics published also after 2000 and includes, for instance, John McLeod's (2004) investigation of postcolonial metropolitan London; the walled and bounded cities inscribed into the topoi of Babylon and New Jerusalem (ValeriaTinklerVillani 2005), the city as theatre and the theatre as its representative institution (Jean E. Howard 2007; Lewis Mumford 1961). Further on, there is focus on cultural constructions and mythologisations of particular places in the city as well as a predilection to understand the synecdochically rendered city as a "collection of places' (an urban museum), such as the East End, (Paul Newland 2008) or specific institutions including prison houses (Jean E. Howard 2007). While Peter Ackroyd (2000) creates an anthropomorphic image of the city's body, imitating allegorical city maps and writing the city's biography, Richard Lehan focuses on more abstract models (1998). Approaches underpinning Norman Davies's Microcosm: A Portrait of a Central European City (2003) are process-oriented in following relational rather than visual strategies. A non-fictional study of Wratislavia the book, commissioned by the city council, invokes the totalising concept of a city portrait only to converge around its ongoing mutations. In Davies's account the city in process changes its name more than fifty times (xvii). Underneath the plethora of superficial diversity, all of these publications recognise the city and 
a methodological cityism as the core concepts in their explorations. It is noticeable that more recent approaches to urban studies appeal to opening up these traditional parameters, to "give up the ghost of thinking in terms of absolutes" (Merrifield 2013, xv) and to address the notion of urbanism as process.

Among recent literary studies, Mapping the City-Narrating 'Complexity' (2015) by Berit Michel is more in agreement with the new approaches to urbanisation. It commences its survey with the city concept only to acknowledge the growing importance of urbanism and extraterritorial networks in representations of urbanity. Michel analyses a collection of contemporary Anglophone urban novels - among them China Miévil's The City and the City, Jonathan Safran Foer's Extremely Loud and Incredibly Close, and Norman Klein's Bleeding Through: Layers of Los Angeles 1920-1986 - as forms of cultural practice by referring to a selection of key-terms including the 'reader', 'space', 'city inhabitants', and the relationship between the 'local and the global'. Considering the experimental form of the novels, the study emphasises the active role of the reader confronted with a city topography (76) which requires his participation and an individualised practice of reading. No longer a passive consumer guided either by a flâneur or an omniscient narrator, the reader, like in Vladislavić's $P K$, must choose his own path thus co-creating the urban image. The former staple categories of space and place undergo a process of deconstruction via a series of revisions where the established architectonic concepts (9), planning practices and mapping tradition $(19,51,84)$ merge with utterly subjective synecdochical narratives which multiply individual impressions preventing the construction of a coherent city image. City dwellers as multitude replace omniscient narrators and privileged character viewers so that, according to Michel, the flaneur's mindset is replaced by the mindset of the city inhabitants (13). The former bounded city bursts becoming more of a system of layers and networks where a chance for orientation and personalization depends more on digital tools than finding one's bearings in geographical or architectonic terms (98). Finally, though Michel does not refer to planetary urbanization, he recognizes the need to introduce the concept of an "urbanized environment"(111) which functions locally but at the same time plugs into global networks so that the former bounded city concept becomes invalid and the city becomes an often virtual intersection of the local and the global.

Post-millennial critical urban theories ${ }^{6}$ absent or incidentally called upon in literary studies of urban contexts, subsumed under the umbrella term of planetary urbanism, challenge the long-established assumptions regarding the urban as city-centred. As a result of the massive transformations after the 1980s, ${ }^{7}$ they have assumed that the polymorphous mosaic of developments could not be adequately captured in terms of the former areal models (Brenner and Schmid 2015: 151). Hence the persistence of such categories as city and cityness seems to result from their ideological function and cultural tradition rather than genuine territorial usage (Brenner and Schmid 2015: 152) as categories of analysis (Wachsmuth 2014: 87). If this be the case, the familiar city concept becomes a representation of people's imaginary relationship to urbanisation, a category arising from 
political practice, as Wachsmuth asserts (77), and thus a concept aligning with ideology. The 'city' becomes "a 'representation' of the imaginary relationship of individuals to their real conditions of existence" (Althusser 2001: 162), often a product of desire for some sense of guidance, a regulative idea rather than a cognitive instrument, and thus leading to misrepresentation instead of knowledge. ${ }^{8}$ Vladislavić's Alibia (in $R S$ ) serves as an example of an urban imaginary, associated with apartheid, a model that disintegrates and belongs to the past.

Representations of the city designed as politically useful mediators and portraits of urban life as well as ideological conceptualisations of government in both cities and city-states are common and have been preserved in literary texts. London as camera regis relates the orderly city to legitimate political power and the image includes a necessary collection of attributes such as walls, towers, gates and bridges as well as the cathedral. The clocks in this orderly image merit a separate chapter, as in John Stow's Survey of London (1603), as a guarantee of order in the city and across the whole country, where their equivalents tell the same time. As opposed to these stable allegorised and regulative images of order, London comedy reveals the unpredictably developing city whose centre is the bustling exchange and the streets with their multicultural crowd as, for instance, in William Haughton's Englishman for my Money (1598). While Stow surveys, disciplines and informs the citizens about their rights and obligations, Haughton is more interested in transgression. Vladislavić, like the seventeenth-century authors of city comedy, prefers to concentrate more on the overwhelming urbanisation processes bursting the constraints of apartheid than on the tenacity of cityness and its ideological function. Still, the reader discovers several intertextually evoked images of 'exemplary cities' to be followed by the story of their dissolution. The reader finds the ideal city of Alibia in "The Proofreader's Derby", Part Two of The Restless Supermarket. Alibia also appears in the form of a painted utopian image covering the entire wall of Café Europa - not a "Florentine fresco", as Aubrey Tearle observes, but atmospheric and of great sentimental value ( $R S 16)$. Café Europa itself is located in Pretoria Street, a name that makes the reader think about the academic reputation of a city with three universities as well as The Voortrekker Monument, located in its southern part - another significant landmark nostalgically evoking the past. Both the academic and the nostalgia-stricken suburban Pretoria in the "American style" belong to the past, either as the narrator's childhood memory in Portrait (34) or as the elitist milieu Aubrey Tearle misses:

\footnotetext{
After a week of fruitless wandering around the streets of Hillbrow ... an escalator carried me up into the Café Europa on the first floor of Meissner building in Pretoria Street.

The ambience appealed at once. There was a hush in the din of traffic, a lull in the beat of sunlight ... At the grand piano was a woman in a red evening dress ... She was playing 'I love Paris', which suited the establishment. (RS 21)
}

Among the idealising city topoi, the desirable imaginaries, Venice remains a lasting aesthetic project which serves as a utopian other. Johannesburg, called the 
Venice of the South ( $P K$ 90), is a man-made stage whose painted backdrop transforms mine dumps into hills and has the forests planted as artificial scenery. Enjoying its artistic curiosity, Johannesburg as Venice remains immune to reflections on ethnic conflict and social change. On the other hand, images of East Berlin (PK 32), London (PK 53) and Rome (RS 121), invoked in Vladislavić's writing, differ from the utopian constructs. Their authors are more individualised, by focusing on crowds of inhabitants and therefore appear to be more in rapport with Johannesburg experiencing socio-temporal transformations after apartheid. While East Berlin is the subject of an exhibition on displacement with its inhabitants suffering from the loss of familiar signs - unscrewed plaques, overturned pedestals and missing monuments - Rome brings back the memorable motif of the fall of a city invaded by barbarians, Sacco di Roma. Visiting the exhibition on displacement (authored by Sophie Calle) the narrator encounters a black boy stealing toilet paper from the cubicle. The boy-intruder is swiftly removed by a guard. The photographic glimpses of displacement in East Berlin conflate with the more tangible sense of displacement in Johannesburg. For the reader, who shuttles between the experience of spotting the child in the washroom and the painful exhibits, the two worlds of images merge into a unique experience of displacement. There is a significant difference between the fragmented Johannesburg and the London "invented" by Dickens ( $P K 53$ ) even though Vladislavić comments with approval on the novelist's invention of walking the city at night in the Sketches of Boz. Commenting on Dickens, he points to the enthusiastic "collaboration" between London and the Victorian novelist "blessed" to live in a city offering miles of streets - a "conversation" and sometimes an "argument" ( $P K$ 54). Dickens employed large casts of characters inhabiting London's multifarious society. Still, he used central characters focalisers assisting the narrator as mediators between the reader, who may remain passive and aloof, and the experience of city materiality - a centralised mediation Vladislavić strives to avoid foregrounding his strategy in the quoted references to the well-known totalising 'representations' of urbanity. Moreover, an important aspect Vladislavić misses is that Dickens walked a certain part of London only, the 'Dickensian London', and thus created a powerful image which confused and misinformed his readers all over the world.

Vladislavić brings to our attention the historical and contemporary images of cityness only to dispel them as either purely ideological or nostalgic constructions. As models of urbanity they belong to the past and no longer provide adequate cognitive instruments for a contemporary explorer. Hence the task of the collection of vignettes in $P K$ is to prevent the reader-walker effectively from constructing a morphologically homogenous image of Johannesburg. Instead of building up the image of Johannesburg, the itineraries encourage concentration on individual, isolated encounters emerging from the everyday experience gathered meticulously in snapshot-form during the twenty years of their writing. To read $P K$ is, according to James Graham, to "bring into being an imaginative space that exists in a tension between individual memory and the possibility of 
a different kind of communal future" and in that way to experience an encounter with a possible city (2008: 334). The encounter with the black boy at the Berlin exhibition, The Detachment/Die Entfernung, provides a stimulating example of collecting experience. What Johannesburg can there be outside the museum? As a result, the reader is invited to travel between the particular offered in a vignette and the possible he imagines. The reader is co-creating with the aid of individual memory (or the imaginary) confronted with the social (collective memory) to develop the possible rendering of Johannesburg as a revision-in-progress predicted, as Graham suggests, on an ethical imperative of openness. Critical urbanism, showing little interest in ethics, relates this openness to ongoing urbanisation and the globally experienced demise of the bounded city concept.

The mental map Kevin Lynch designed in the late 1950s, proposing five key images - paths, edges, districts, nodes and landmarks (1960: 4) - and dependent on an abstract "urban form", hardly corresponds to urban experience, including that of post-apartheid cities. His theory functions neither as a map nor as ideology whose task is to mediate between the existential and the scientific. Fredric Jameson defines the latter condition as a moment of crisis revealing the need of a new cognitive map (1997: 53). Despite change, the map proposed by Lynch does not disappear entirely. It may serve as object of heritage nostalgia. Accordingly, the title of Vladislavić's Exploded View foregrounds the loss of the former map and points to the rise of new relations. Considering the historically exploded landscape of Johannesburg which appears on the covers of $P K, E V$ signals that destruction is the precondition of new social and urban activity. Here it is the dismantling of a traditional city portrait, signalled in the opening passages of "Villa Toscana", which gives information about the collapse of former boundaries superseded by entirely artificial, culturally displaced urban constructions:

The boundaries of Johannesburg are drifting away over pristine ridges and valleys, lodging in tenuous places, slipping again. At its edges, where the city fades momentarily into the veld, unimaginable new atmospheres evolve. A strange sensation had come over him when he first drew up the gates of Villa Toscana, a dreamlike blend of familiarity and displacement. (Vladislavić 2004: 6)

Johannesburg not only expands by invading the veld, the rural, but its extensions take the form of security villages (a puzzling term as the country traditionally denotes safety) which are architecturally alien, unhomely and not village-like in their foreign styles, whose entirely fictitious character, in the case of Villa Toscana being its gothic style, has been invented and distilled from popular culture rather than transplanted from any, even far away, reality of the Italian countryside. The effect is genuinely surreal, blending familiarity with the uncanny.

To explore urban development, nineteenth-century Victorian urban literature, employs the narrator/character-focaliser that performs an essential role in the process of capturing the city image either as fixed or as dynamically open and 
more susceptible to change. Even modernist narratives overwhelming the reader with myriads of impressions, have central characters whose guidance in the cognitive process is essential and produces the effect of the city as a central category. Vladislavić's writing, notably $P K$ and $T J$ Double Negative, is to a considerable extent autobiographical, a form which promises guidance from the implied author. As a form of life-writing, especially $P K$ raises the question of the way an autobiographical self engages (as focaliser) with change and time flow in general, and in relation to the urban environment in particular. An analogous difficulty appears in Philip Ridley's "Introduction", where each "I" in the subsequent snippet is different even if the time distance between them covers barely a few minutes. The "I" is fictionalised in the process of writing once it commences but in Ridley's account never solidifies in a homogenous character - it becomes a collection of figures whose perception of the East End remains fragmentary. Analogous fragmentariness governs $P K$. The official biography on the homepage of the University of the Witwatersrand (Johannesburg), where Vladislavić has been teaching creative writing since 2015 , refers to $P K$ as a memoir, while critics, for instance Patrick Lenta, tend to emphasise the autobiographical (2009: 122). ${ }^{9}$ Variously classified, the vignettes in $P K$ appear to be generically complex so that the relation of the self to urbanity poses an interpretational difficulty. If categorised as literary non-fiction, the vignettes render personal experience, obliterating the differences between narrator and focaliser, empirical author and implied author. Lenta and Goodman propose to define the narrator in $P K$ as a type of flâneur, though they notice essential differences between the nineteenth-century construction Anke Gleber defines as a "privileged mode of recording the external world" (1999: 4) and the marginalised position of Vladislavić's walker (Goodman 2011: 283), whose narrative often becomes dialogic. The narrator is neither a detective nor a reporter-observer capable of collecting empirical data in a scientific manner, and prone to ratiocination. There is no flâneur in Vladislavić's vignettes. Neither does Portrait concentrate on an autobiographical project. On the other hand, if Portrait with its focus on the external is a memoir, and I would argue that it is, it states the impossibility of autobiography and targets the outside in dispersed memories - reliable, unreliable and fictionalised - rather than foregrounds the writing "I" offering an expert that will construe a 'representation' of the city. Thus the narrative does not contribute to a re-collection of a bounded city but offers dispersed insights. Additionally, the unreliability of memory invites speculation and triggers off the activity of the reader in co-creating Johannesburg.

Decentred and dispersed temporally among cognitive tasks, Vladislavić's first person narrator is additionally deprived of special access to scopophilic aerial shots that customarily reveal "the spread of urbanity in a panoramic, fictitious 'bird's-eye perspective", a privilege enjoyed by the traditional flâneur (Gleber 1999: 14). The aerial view closing Part A, accessible on aeroplane departure from Johannesburg, invokes de Certeau's "imperious voyeur-gods" to provide but a brief moment when the city becomes "comfortingly explicable" (Vladislavić 2009: 103). This moment of cognitive certainty and access to the familiar is 
interrupted to reveal an aesthetically pleasing but unclear image of the city as "a web of light"(103), a motif found already in John Bunyon'a blurred image of New Jerusalem in Pilgrim's Progress - a refusal to grant access to the otherworldly. The aerial view facilitates the customary disentanglement from personal connections the narrator has indulged in but offers no compensation - it is an urbanity whose defining landmarks have been erased (Vladislavić 2009: 103). The expectation of a correct point of sight ends in disappointment. The view fails to provide knowledge, i.e. access to the 'chronicle' of the streets, to a properly gathered public memory. Unable to grasp the urban traffic as a whole - the once clearly regulated gates of access, entrances and exits have disappeared - Vladislavić decides to problematise the diversity and ambivalent function of gates, especially in the vignettes focusing on tomasons and "vanished gateways" (Vladislavić 2009: 174). In spatial terms, Portrait concentrates on passages: they become thresholds, multiplying and expanding. Johannesburg emerges as "a place of contested boundaries" (Vladislavić 2009: 173), whose territory is persistently Janus-faced, amorphous and in danger of disappearing. ${ }^{10}$ The motif of "looking back" dismantles even the aerial view (103). With the fixed boundaries gone, the city is gradually dismantled by new forms of activity. Scavenging and rag-picking, as forms of mobility and ways of knowing, do not involve either landmarks/sights or aesthetically-inclined collecting, but denote experience and survival. Hence even these activities, once the prerogative of an alternative flâneur, acquire a different meaning.

As opposed to $P K$, in the earlier published $R S$, Aubrey Tearle, the walking writer-editor-narrator, like a bourgeois idle walker, enters the public sphere trying to 'read' the text of the city, its architecture, urban design and inhabitants, foregrounding in that way a nostalgia for the modernist flâneur and his city. However, both Tearle and the modernist flâneur belong to the past, so that the character's eccentricity is as obvious to the readers as it is to the fellow-characters. The typographic concept of the cityscape, the city-book, and the understanding of walking as reading are anchored in William Hazlitt's essays, introduced as a text of authority via the epigraph to "The Café Europa". ${ }^{11}$ Seeing as reading, proofreading and editing characterise Tearle in his effort to grasp and stabilise the urban materiality in the form of a perfect typeset text. However, the proofreader's endeavours to contain urban processes within a fixed form turn out to be futile. Moreover, they are mercilessly ridiculed by his companions as outdated: the enframing typeset falls apart and, as a result, the text becomes more and more infected by errors and gapped, rendering its completion impossible. Ultimately, the city view, as an increasingly incomprehensible text, is metaphorically taken over and consumed by maggots, its new readers, "battening on the foul proof of the world" (Vladislavić 2014: 298). While in $P K$ the multiple first person narrators assumes the role of story-tellers immersed in the urban environment adopting the mode of oral transmission (admitting greater flexibility and easily adjusting to new contexts), Aubrey Tearle's writing is rooted in the rigid materiality of the book and the archaic art of printing which remains immune to change. When ur- 
banity merges with nature (the former country) and becomes a biological organism the worms consume - an obliteration of categories emphasised by adherents of planetary urbanism - Tearle simply lacks the knowledge of the cotemporary languages that would let him decipher the multiple texts of the new urban developments. He would have to proofread texts in languages he does not know, a sad prospect of proofreading the Pentateuch in isiZulu (RS 290), where the proofreader is reduced to an ox in ploughing.

In $E V$ the deconstruction of concept-cityness is announced in the very title. Four character-narrators, including the commercially predisposed artist, the billboard constructor, the census agent and the sanitary engineer are granted expertly specific access to the expanding urbanity so that no morphological city pattern can be either deduced or reconstructed from the available scraps. Gordon Duffy's incessant automobility helps enact a contemporary version of a walker rather than a romantic wanderer. Duffy, a car/driver hybrid (Thrift 2004: 46-47), a manmachine, is no longer a free rider of motorways. His consciousness is imprisoned (Vladislavić 2004: 160) in various non-territorial communication systems. Graham refers to an "automobile matrix" (2007: 76). Duffy experiences mediated access to the urban environment. Indeed, in $E V$ Vladislavić consistently defamiliarises the habitual engagement of the flaneur as a city connoisseur in order to demonstrate his limited cognitive potential and, ultimately, the ineffectuality of the flaneur-device in times when the object of urban exploration is no longer the high-modernist city. The traditional stroller provides no proper key to the continuously exploding and imploding urban assemblage.

The sense of the surreal in $E V$ grows with the importance of augmented space and augmented reality, i.e. "physical space overlaid with dynamically changing information, multimedia in form and localized by each user" (Mannovich 2006: 219). It pervades "Crocodile Lodge" where the narrator-focaliser is not only an addicted phoneur, but a billboard constructor immersed in the restless supermarket of global commercials his constructions enact and propagate. Even his mobility along freeways is determined by the virtual networks he is plugged into, "a map of sensations keyed to his body" (Vladislavić 2004: 159), a traffic regulation system which supervises the constructor's safe behaviour. Guided by the networks, the builder reaches construction sites whose location in the unmappable cityscape remains unclear. "Villa Toscana", another part of $E V$, converges around a gated community in the Italian style, a heterotopic corporate enclave, immersed in a network of fictions in the gothic style, where the empirically minded census agent experiences an acute sense of disorientation when he is unable to distinguish between the empirically conceived reality his questionnaire should probe and the television world of the continuity announcer he is interviewing (Vladislavić 2004: 23 ); his world of lucidly formulated questions and her world of virtually constructed identities, language competence, memories and scents - the dream-like reality epitomised by the Perfumed City of her bathroom (Vladislavić 2004: 34). These diverse interfaces, ${ }^{12}$ including the virtual networks, tend to disable and replace the former visual order with its fixed, allegorical concepts of the bounded city. 
The former national-developmentalist city model, the new urban approach contends, has been replaced by complex governance due to emerging transnational market-oriented relations and new land use. ${ }^{13}$ Among its effects there is gentrification (Brenner and Schmid 2015: 153) and the rise of gated communities (as Villa Toscana in $E V$ ) or secure villages. The complexity of the urban processes is reflected in the appearance of new lexical items showing a preference for diverse networks. The phrase, "restless supermarket", which gives the title of Vladislavić's 2001 novel, provides an example of this new vocabulary, a phrase which sounds confusing to old hands like Tearle, the white proof-reader in $R S$. He explains to the supermarket owner that the name of the outlet the man coins, the Restless Supermarket, is incorrect and "creates the wrong impression" as "[o]ne thinks of mess, of groceries jumbled together "or "jumbling themselves together, of wilful chaos"(Vladislavić 2014: 87). While to Tearle the name remains incomprehensible, to Stelios, the Greek owner, the newly coined meaning of "restless" is more than adequate and as obvious as the liberal commercial order that requires shops to be open round the clock. It signals the new social policy granting open access to citizens as consumers. The city of Johannesburg, becoming a restless supermarket, enters the borderless and time-less global network of a marketing system but, as a metaphor, the "restlessness" reveals what Brenner and Schmid define as the "unevenly woven, restlessly mutating urban fabric" (2015: 170). Reflecting on urban change, Mukherjee argues that the aim of writers like Vladislavić is to register this "unevenness", which involves a whole spectrum of political, economic and spatial aspects of social existence (2012: 475). Nothing is fixed in this unstable landscape. The former city as citadel, under whose aegis violence was normalised, no longer controls anything, not even crime. As a result of this disintegration, in $R S$ whole parts of the city's materiality are disappearing:

What was fixed anyway? There were people, deprived creatures without garages, which resorted to chaining their cars to trees at night to secure them against car thieves. But that faith in growing, rooted things was misplaced: there were tree thieves preying on the municipal flora. As fast as the Parks Department planted trees and shrubs on traffic islands and freeway embankments, thieves dug them up and carried them off ... Another species of thief stole manhole covers and sold them to scrap metal dealers. Yet others specialized in bus-stop benches and kerbstones, street signs and fences, water pipes and electricity cables, milestones and monumental masonry ... Entire houses had been stolen by these cannibals, even schools and factories. (Vladislavić 2014: 115-116)

The disintegrating control and the intricacy of relations, where terror mobilises defensive violence, pervades several routes in $P K$, for example "Engaging the Gorilla", "Security" or "Safe and Sound", contributing in that way to a radical re-mapping and restructuring of the city and its concept. Referring to the Shakespearian dichotomy of Rome and wilderness, the narrator notices that Johannesburg experiences a return of the wilderness or jungle with its "hunters-gatherers" (Vladislavić 2009: 39), a process which obliterates borders and dismantles bina- 
ries, including the seminal difference between the urban and the rural. Further on, the personalisation of public space through its domestication creates an alternative network of social relations, among others, a "transformation" of public space into "repositories of privacy" (Vladislavić 2009: 50), "secret places" beneath the soles of the unaware pedestrians. At the same time there is a massive appropriation of private space by kleptomaniacs stealing personalised objects, including life-stories (Vladislavić 2009: 80), which leads to general disorientation and a growing sense of the surreal.

The rise of PU does not eradicate the concept city from urban literature. New concepts in urban writing are often paralleled by a continuation of earlier-established paradigms of the "urban age" where "urban age" remains the metanarrative of the twentieth-century. If nothing else, the lingering Cartesian fiction of knowledge is recalled to reveal its inapplicability and to show the resulting frustration among its adherents. As Vladislavić observes in vignette 2, it is not the knowledge of the map, but "getting lost" (Vladislavić 2009: 17) that is desirable, only to add that misdirecting a stranger is "for his own good" (Vladislavić 2009: 17). The city needs not to be explored with regard to its familiar streets and typical architectural features but as city in process. An analogous idea becomes the basis of "Urban Tapestries", a research project started in 2002 that investigates the use of modern technologies in experiencing and knowing the city. The research concerns the ways geographic information systems and mobile technologies (including open access Wi-Fi) affect the ways people experience urbanity and share the experience creating, in the course of public authoring, an inclusive, diverse and overlapping image of the urban environment. Carlton Centre in $P K$, like the WTC in Jonathan Safran Foer's Extremely Loud and Incredibly Close, disappears as an ordering principle. Vladislavić recalls that completed in 1972, Carlton Centre was an "enormous complex" ( $P K 29)$ with "an air of supreme sophistication" (29). Still in the eighties, visited by tourists, the tallest building in Africa, Carlton Centre is no longer a landmark but becomes a place where visitors risk being hijacked or robbed. Vladislavić locates the Carlton Centre vignette 11 significantly in the path entitled "Beggars and sellers". Oskar's traditional map in Extremely Loud becomes an important narrative detail, but it leads the boy to despair over its deficient guidance. The same applies to the multiple keys in Foer's novel and in Vladislavić's $P K$. On the level of social practice, collections of keys signal insecurity and barred access ( $P K$ 115-116). Unlike the symbolic keys to Vatican, the multiple keys in the golden city point to the absence of a centre, a landmark or a dominant paradigm, a correct map or a suitable key-hole demonstrating, in that way, the unpredictability, intricacy and illegibility of the urban environment- the contemporary episteme.

Since 2007 over half of the world's population lives in cities, a fact frequently quoted, especially by empirical studies which have the city defined in reference to a myriad of indicators Brenner and Schmid perceive as often arbitrary (Brenner and Schmid 2015: 156) and proposed by census agencies. Systematic, empirical studies focus on the development of communities, their way of life, as well as 
on the role of institutions separating clearly objects from process (Walker 2015: 185). They go back to positivism, postmodern approaches confront the same way they challenge the modernist theory of planning, but tend to weave in universalising outlooks, subsuming the urban process under the encompassing lens of cityness. For Vladislavić urban theories are not valued for their scientific merits but serve as enlightening sources of inspiration that correspond to or interact with immediate experience. Hence he is more likely to concentrate on consumption, creation, image production, as well as the textualisation and digitalisation of city materiality. In $E V$ the futility of the empirical approach is announced explicitly. Among the leading characters, it is the census agent who turns out to be genuinely obsessed with precision in constructing his research tool for collecting empirical data, a questionnaire. It is also the agent who is entirely befuddled when exposed to the heterotopy of Villa Toscana.

\section{Towards planetary urbanism}

Building on reflexive approaches to critical social theory, PU proposes a 'reflexive' epistemology of the urban, assuming that epistemological reflexivity insists on a situatedness of all forms of knowledge as well as on a mental constitution of the subject-knower and object, i.e. the site of investigation (Brenner and Schmid 2015: 159). This explains why, in the theatre of urbanity, stabilising viewpoints including flâneur-like focalisers and other 'outsiders', spying on the city from their comfortably isolated seats, are either marginalised or eliminated - as in $P K$ and $R S$. Aerial views and disembodied scopophilia prove to be poor sources of knowledge. The urban fabric must be explored through encounters and due to multiple, contextualised focalisers whose experience partly overlaps with that of the implied reader. Leaving behind the earlier ocularcentric propositions, PU is attuned to multiplicity and often extra-territorial webs through which developments are mediated (Brenner and Schmid 2015: 162), e.g. Global Positioning Systems or traffic report systems. Both have been mentioned in the context of $E V$, where they stand in opposition to Aubrey Tearle's (the autodiegetic narrator who dreams in vain of becoming a heterodiegetic knower) archaic obsession with typesetting telephone directories and nostalgia for long views $(R S)$. For the proof-reader Hillbrow Tower functions the same way as the bells of St Mary Le Bow, "the Bow Bells" (RS 25), for the East Enders. Finally, having erased the long-established familiar borderlines, PU postulates the inclusion of "rural zones" into the urban - a process involving reflexivity, where the transformations are bidirectional with their cause and effect immersed in a circular relationship.

Reflexivity, a two way movement, is a process which can be traced in Vladislavić's depiction of socio-temporal change where the jungle $(R S)$, the veld $(P K)$ and the wasteland $(E V)$ enter Johannesburg or, as we may conversely assert, Johannesburg penetrates its former outskirts where "walled town-house complexes [are] set down in the veld", inviting the white migrants who look for safety 
and comfort, so that the northern outskirts of the city would regard themselves as the new centre (EV 173-174). In often parodic language, the obliteration of former borders is announced in $R S$, where Europa Caffy - a meeting place once well established in Pretoria Street - becomes the "last outpost of symbolization in the jungly flatland that go by the name of Hillbrow", now the "most densely populated residential hairier in the southern hemisphere" ( $R S$ 17). The former wilderness and the veld are absorbed into the urban as a result of a massive Völkerwanderung involving a complex movement of traffic in the direction of the suburbs and towards the centre. Tearle finds the process documented in the relocation of names and professions in the telephone directories he proofreads, tracing, for example, the influx of "Moodleys and Naidoos into Mayfair" (RS 130-1). The inflow of new inhabitants imports hitherto unknown ways of life. "Joburg", like many other African cities, becomes the home of hunting-gatherers, that is "roamers, intent on survival, plucking what they can on the roadside" ( $P K$ 39). The jungle invades the city, which adopts the regulations of the wilderness. Property rights, notably land rights, have been revised or culturally translated so that law and order must be reinterpreted, as in the case of the Khoikhoi accusing the San of stealing their cattle ( $P K 39$ ). The cosmopolitan but elitist club is taken over by newcomers, called Bogeymen and Bohemians, whose languages seem either foreign ( $R S 138$ ) or "sub-standard" to the elegant world ( $R S$ 139). Migrations revise the legitimising symbolic system (or grand narrative) and require that such concepts as 'cosmopolitan' must be revised or updated in the dictionary so that they can enrich the vocabulary of the new languages, notably the urban vernacular. The relational and reflexive model is compared to a spreading infection ( $R S$ 75). Even Aubrey Tearle, the narrator, is affected by the disease and thus incapable of excluding himself from the circle of cause-effect entanglement:

I caught myself in a mirrored pillar, like an Aborigine scribbled all over with Vat 69 ... I had espied myself there before, ... but never in such a state of extremity. My hair was standing to attention in clumps, ragtag bands of desperate bristles whose company had been routed. ... And then the trolley ... I was stooped over it like a geriatric in a walking frame. I looked like a tramp - worse, like a hobo, one of the bag ladies and gentlemen, the collectors of old iron and empties. ... Had I become one of them? I barely recognized myself. (RS 117-118)

Tearle develops from a writing subject and pedantic proof-reader into a scribbled over Aborigine. The same process affects urbanity. In $P K$ the "township is written in longhand across the printed page of the white city" (64), a demonstration of its palimpsest nature. The "clumps" and "bristles" in Tearle's image bring him closer to the world of nature. The proof-reader's transformation continues and, towards the end, the hospital mirror shows his "blackface" (RS 280) - the face of a slave. Transformations proceed even further so that the clubbers' visit to the zoo undermines their basic understanding of homo sapiens when they discover a human being in the cage and wonder if the creature, like other specimen, is on the verge of extinction. The "we" becomes problematic (154-155) and its inclusiveness 
ambiguous. "Who were "we'?" Tearle wonders realising that nothing is certain. The city is not an object but a "process of socio-temporal transformation" which criss-crosses and redefines places, territories, and scales to produce a complex force field, in literary terms a heterotopy rather than a morphologically singular category. The relational circularity involves crowds of diverse urban inhabitants once proudly called civitas, the cityscape as well as the aspiring narrator who cannot but become one of the ordinary city dwellers. In the two-way traffic Tearle is "denigrated" to let Bogey becomes a club member. In this context, the proposal of a bounded urbanity defined in relation to some "constitutive outside", a privileged institution is useless. It would only obfuscate the process of urbanisation, the ongoing unpredictable implosions and explosions (Brenner and Schmid 2017: 187; Brenner and Schmid 2015: 166). Indeed, Vladislavić appears to write in conjunction with Brenner and Schmid's proposition believing that static approaches must be superseded by ones that investigate "how urban configurations are churned and remade across the uneven landscapes of [...] development" (166). This takes the fluidity of Johannesburg and the situatedness of knowledge for granted. Even the writer/editor becomes object of socio-temporal transformation.

Traditionally, urban theories focus on growth, i.e. on agglomeration and conurbation, while PU, indicating the inevitable paradox inherent in city-centred approaches proposes, focusing on a more multifaceted process of change. While the traditional hegemonic dispositif faces an analytic problem when trying to combine bounded urbanisation and growth (Brenner 2017: 216), Brenner and Schmid distinguish three processes comprising concentrated, extended and differential urbanisation. Appropriately, they prefer to use terms such as "urban fabric" and "operational landscapes", consolidated through active production, rather than referring to the "hinterlands" (Brenner 2017: 220), the country, the "outside" or the "non-city". Due to global mobility, relations with hinterland regions have become more complex and dependant on their economic relations with the city as well as other distant locations. In $R S$ the homogenising factor is the market, hence the idea of "restlessness", turning the multifarious, groups of urban dwellers - independently of their economic status - into consumers, addicted window-shoppers (137) sharing in the benefits of the market. The earlier terms denoting binaries evoke the old boundaries and indicate a clearly defined mode of growth. Therefore PU must generate a new vocabulary. It can be argued that Vladislavić, struggling to grasp urban transformation in terms that avoid the old binaries, focuses first on communal life where he avoids spatial concepts by focusing on urban dwellers. He draws attention to the rapidly disappearing distinctions including the differentiation between the private and the public, whose annihilation has far reaching consequences for the urban milieu. Café Europa, a tiny gathering of connoisseurs Tearle identifies as a "club", and thus a public institution, develops into a "family" ( $R S 40)$ - a private gathering - whose members are not chosen on the grounds of their intellectual alertness. They have just "pulled in", like Evaristus (a bottle-washer), and "could park off" with the former members "and have a fresh orange" (RS 40) as times have changed and nobody questions their "rights 
to the city'. The very idea of a Goodbye Bash, defined as a "reunion" (RS 39) by the organisers, takes a new inclusiveness for granted, so that the party becomes an event that promotes post-apartheid egalitarian concepts and tests the 'flexibility' of its participants. To some extent, metaphorically, it probes the resilience of the growing community. Lack of respect for the old regulations differentiating the public from the private results in a less desirable understanding of the right to the city, i.e. in massive dislocations of public property - disappearing bus-stop benches and kerbstones, street signs and fences. Nothing is "fixed" (RS 115) so that "[e]ntire houses had been stolen ... by cannibals, even schools and factories" ( $R S$ 116), the narrator observes, to stimulate growth in other locations happening during the night. Infringement of private property is common. Analogous motifs pervade $P K$, where paths devoted to security, walls, locks, self-storage and 'engaging the gorilla', paradoxically, become a measuring stick of the ongoing process of dissolution where earlier settlements disappear. Further on, urban investment has no respect for the old buildings fitted with Italian marble and Rhodesian teak. One building after another, street after street are pulled down Murray Street, Scott Street and William Road (PK 70). The old Johannesburg is disappearing.

This palimpsest overwriting, the result of social transformations, like the drawings of William Kentridge, produces a sense of temporal and spatial complexity rather than morphological homogeneity. The veld in vignette 127 reveals its history of land use in the collected waste: leavings of a mine, porcelain insulators, black ash, half a brick, and wing bones Vladislavić identifies as inscriptions or signatures in the expanding cityscape ( $P K 170$ ). The land as the former "outside" is more prominent in Exploded View providing insight into the processes of unsupervised concentration and deconcentration. In "Crocodile Lounge" and "Afritude Souse" $(E V)$ the operational landscapes, installations, sewage system, motorways and freeways come to the fore while the vocabulary of hinterlands and the veld, as "the other", belong to the past. Urbanisation proceeds along these infrastructural paths. Wastelands along motorways denote cheap land swiftly appropriated by new inhabitants. Here housing development is either organised formally under the aegis of the Reconstruction and Development Policy or informally as a "clutter of corrugated iron shacks" (EV 20) springing up between roads and freeways. Unpredictable in its development, urbanity becomes a force field of implosions and explosions of activity generating "differential moment[s] of urbanization based on a perpetual drive to restructure sociospatial organization" (Brenner and Schmid 2015: 168). To define the properties of the no longer homogeneous "urban deferential space (time-space)", we can call upon Lefebvre's concepts of heterotopy versus utopia (2003: 37). The utopian gesture emerges as a significant point of reference in the image of Alibia $(R S)$, but most of the urban space Vladislavić evokes takes the form of heterotopy, mingling and mincing the former neatly isolated binaries of city versus country or real versus surreal and virtual.

Territorial regulations enumerated by Brenner and Schmid include collectively binding rules regarding, for example, appropriation of land, infrastructure and 
commodity circulation - invoked in the preceding discussion - as well as a mobilisation of formal and informal government patterns and territorial developments (Brenner and Schmid 2015: 170). Thereby they propose an epistemology which entails the loss of fixed city-oriented categories and focuses on process. In the context of Vladislavić's depiction of Johannesburg, the cohabitation of concepts derived from diverse theories requires some comment and a return to Lefebvre. If everyday life, Lefebvre warns in The Production of Space, "remains in thrall of abstract space" and in that way under the control of the "agencies of political power", it is truncated (1991:59) offering no true insights into the new ways of life and processes of urban development. Therefore, when the concept-city as abstract space remains an agency of political power - preserving the relics of apartheid, for example - everyday life's functions remain coextensive with the theatricality and mise-en-scene of the 'representational' city and their meaningful application becomes impossible. Lefebvre gives the example of Venice which Vladislavić also quotes as a representational aesthetic project ( $P K 90)$ which brings together a flaneur or a tourist, rather than a city dweller, and the urban. The narrator insists that the walker, or driver, engaging in a conversation with the "way" must write the "poem of walking" in the form of a genuine dialogue ( $P K$ 53). In $R S$ Vladislavić disassembles the utopian concept city, the fake apartheid dream of multilingual and multicultural cohabitation, as well as the Europeanstyle city supervised by Café Europe, a locum where conversation waits to be replaced by dialogue, and where the domination of correct English is giving way to the rising plethora of languages. A successful dismantling of the apartheid narrative becomes a precondition of genuine everydayness. This disentanglement from the former symbolization liberates the inventiveness of Johannesburg and becomes proof of her resilience, a flexibility allowing for new forms of cohabitation. In $E V$, the former apartheid walls and gates securing the racial segregation of Johannesburg are replaced by multiple gated communities exercising double but dispersed segregation. Villa Toscana, an eclectic appropriation of the European tradition (Vladislavić 2004: 7) - no longer in style - is policed by a black guard, a former 'other' or 'alien', whose uniform and gothic monster-biro (7) transform their bearer into a curios domesticated protector, now in charge of control and a new segregation. The reversal of roles is not essential. More importantly, the gothic guard becomes a hopeful monster in the newly created community. Artistic creativity thrives and its proof is not only in the list of 16 recognizable artists listed in $P K$ but, among other projects, in the Ndebele murals introducing Africa "in the nicest possible way" to the once white suburbs $(P K 28,60)$. There is also Jeff's artistic scheme for raising a wall of remembrance to commemorate every person in the Greater Johannesburg area - a communal project resisting the impact of transformations in an attempt to stabilise collective memory. The unsettling of former spatial and social boundaries asks for a remaking of the former cognitive map of social segregation (Bremner 2004: 460) to trace the newly co-created practice avoiding the former pathologies of space (Lefebvre 1991:63). Vladislavić, as if following the findings of planetary urbanism, withdraws from 
the constructions of the familiar 'representational space' as well as refuses to become engaged in its 'representation'. Rather, involving in micro dialogues and encounters, and sharing in the first person plural narrative ( $P K$ 47), in Portrait in particular Vladislavić reveals a city of subtle negotiations inviting the reader to join the "we" of the first person narrator (implied author) and his subsequent interlocutors to co-create the possible city - a participatory rather than purely aesthetic project.

\section{Conclusion}

Vladislavić's urban writing - The Restless Supermarket, The Exploded View and Portrait with Keys - is situated in the identifiable cityscape of Johannesburg and its outskirts, tied to a definite historical context, and consistently responding to its transformations. Expanding neo-liberalism, rampant consumerism and diverse forms of segregation as well as conflicts concerning land ownership are all mirrored in a writing that avoids political manifestos trying to adopt a policy of openness to a multiplicity of diverse voices. The novels or short stories and collections of snippets and vignettes trace the subsequent transformations of the famous city by referring to historically traceable forms of urban development including gentrification, sprawling, gated communities, formal RDP developments and informal settlements, migrations and socioeconomic discrepancies marking the lifeworlds of Johannesburg's inhabitants. Further on, the writing relates to more specific reconfigurations, including the dislocation of famous landmarks and the appearance of new urban signs such as Ndebele murals, piggy walls and smudges replacing the neat print on plaques. The writing endeavours to explore the possibilities of understanding transformations in post-apartheid South Africa by focusing on urban change, a strategy based on the assumption that the urban environment remains of primary importance in contemporary political and cultural discourse, and may serve as a contemporary episteme. Hence, first of all, in search of a new epistemology of the urban Vladislavić does not so much "invent" an entirely new cognitive instrument as much as he foregrounds and interrogates the inadequacy of concepts and nostalgically preserved categories used in earlier urban theories - concepts rooted in the spatial category of the morphologically pure bounded city as a key concept. Only later on does Vladislavić, experiment with new theories, notably planetary urbanism. In agreement with new urban theories, Vladislavić concentrates on processes. Static, spatial categories associated with morphologically definable settlements are replaced by attempts to grasp the vibrant, unstable materiality, the dynamic changes and processes. The spatial concepts based on binaries, a system of landmarks and the control of an external institution (political authority, narrator, flaneur) succumbs to forms of mobility, so that the 'city' is replaced by 'urbanism' and an amorphous urban environment overflowing and dismantling the former borders to challenge the constitutive binary of centre vs. veld. Vladislavic traces the inapplicability of the 
established city vocabulary, demonstrating a dissolution of the materiality it used to address. To comment on the dynamics of transformations the author focuses on experience. Vladislavić invokes the current socio-temporal processes addressing the city as its multicultural and multilingual citizens engaged in the process of inhabiting and expanding the urban. The relational assemblage of voices becomes even more inclusive due to the narrative technique privileging plurality, a sequence of first person plural and singular narratives where the number of interlocutors remains unclear. The first person plural invites other participants, including the reader, while the fragmented first person singular, in $P K$, resists homogenisation into subjectivity. The brief vignettes in $P K$ conspicuously enhance the fragmented, incomplete nature of experience, drawing the readers' attention to the temporal gaps between the snapshots, i.e. to the unknown and unpredictable the reader may speculate on contributing, in this participatory mode, to the imagined possible city image. What can Johannesburg reveal of its future if not another enigma?

\section{Notes}

References to 'planetary urbanism' will appear either in abbreviation or as PU.

There has been noticeable interest in subterranean or 'underground cities', e.g. Neil Gaiman's Neverwhere, or Matrix written by the Wachowski brothers. However, Vladislavić's writing does not create either underground mythologies, the mysterious "other", or the fantasy worlds David L. Pike describes in Subterranean Cities. The World beneath Paris and London (2005: 211, 290). Vladislavić's interest is more fact-oriented and the networks, such as communication networks, partake in daily urban life and development. The following abbreviations are used throughout the article: Expoloded View-EV; The Restless Supermarket-RS; Portrait with Keys: The City of Johannesburg Unlocked-PK. The expression was used by Martin Aboleda (an urban theoretician) in conversation with Neil Brenner (2017: 277). Earlier, it appears in Steve Hinchliffe's technologically-oriented article (1996: 665).

5 In "The Agency of Design in an Age of Urbanization", Brenner identifies himself as "a critical urban theorist" concerned with ideologies of the urban (Brenner, Ibañez 2017: 224).

$6 \quad$ The critical urban tradition developed out of Marxism in the 1970s and was pioneered by Henri Lefebvre, David Harvey and Manuel Castells.

7 The transformations include the collapse of state socialism in Eastern Europe as well as the collapse of apartheid; a crisis of national-developmentalist models and the intensification of economic integration on a local (for example, European) level as well as global. Brenner and Schmid mention the influence of the crisis in the late 2000s and around 2010 (2015: 151). Additionally, in the context of the present discussion, land ownership remains problematic in South Africa since the fall of apartheid, which is reflected in The Exploded View where sudden changes in land ownership provide opportunities as well as encourage shabby urban developments. Land debates are reverberating and the resolution to accelerate land redistribution without compensation affects investors in both agriculture and urban builders.

8 In her analysis of the uses of ideology and theory in the urban context, Gonewardena points to the need of ideology as an imaginary map of social totality and in that way standing in opposition to theory (54). Planetary urbanism does not offer such a simplifying map.

$9 \quad$ Both memoir and autobiography are forms of life-writing, but they encourage different representations of urbanity. While memoir relies on memory and, reworking the extratextual 
past, emphasises fragmentary images rather than chronology and the narrative, autobiography implements a comprehensive narrative project. Moreover, the lyrical memoir enhances the poetic quality of images (G.Thomas Couser 143), which may explain why Vladislavić's snippets in $P K$ can be approached as poems.

The concept of a frontier city in postcolonial literature is frequently mentioned in connection with contested boundaries. However, shifting frontiers do not imply the dissolution of either the city concept or cityness. See Herbert, p. 207.

The epigraph reads as follows: "He reads the world, like a favourite volume, only to find beauties in it, or like an edition of some old work which he is preparing for the press, only to make emendations in it, and correct the errors that have inadvertently slipt in", and derives from William Hazzlitt's essay "On the Conversation of Authors" (78). See The Plain Speaker: Opinions on Books, Men, and Things, edited by the poet's son and published by Reynell and Weight Printers, London 1851.

12 Marais argues that the technical drawing called "exploded view" mediates between the individual and the social imaginary (30), supplying us with an interface. Moreover, to create, Majara, the artist from "Curioser" in $E V$ needs to destroy, i.e. to 'explode' the wooden masks and animals he uses as source material. There is, however, another aspect of the "exploded view" used as interface and a cognitive tool. In the drawings found in old American magazines, the narrator from "Crocodile Lounge" recalls nostalgically that "things were the sum of their parts" and each "element waited, in suspension, for finality" (EV 171) as opposed to the new reality where finality cannot be achieved but imagined. Hence the drawings no longer provide a guide to reality. Using technology, people no longer understand how it works, an observation which applies to the expanding urban world.

13 In the Restless Supermarket Vladislavić refers to a massive migration of people moving from the country or from black settlements to areas formerly inhabited by white citizens and claiming their right to the land. The sense of displacement is acute. In The Exploded View the problem of land ownership is not openly posed but the author writes on legal and illegal sprawling, mentions the question of deed registration and potential corruption (47), on squatter camps as informal settlements springing up over the night and side by side with formal RDP houses ( $E V 20$ ), which enables them to plug into their infrastructure. It is not just the city infringing upon the veld but a sense of total chaos in land usage.

\section{References}

Ackroyd, Peter (2001) London: The Biography. London: Random House.

Althusser, Louis (2001) Ideology and Ideological State Apparatuses. In: Lenin and Philosophy and Other Essays, trans. B Brewster. New York: Monthly Review Press, 127-186.

Bremner, Lindsay (2004) Bounded spaces: Demographic anxieties in post-apartheid Johannesburg. Social Identities 10 (4), 455-468.

Brenner, Neil (ed.) (2014) Implosions/Explosions. Towards a Study of Planetary Urbanization. Berlin: jovis Verlag GmbH.

Brenner, Neil and Christian Schmid (2015) Towards a new epistemology of the urban? CITY 19 (23), 151-182.

Brenner, Neil (2017) The hinterlands, urbanized?. In: Brenner, Neil (ed.) Critique of Urbanization: Selected Essays. Berlin, Gütersloh: Bauverlag, 212-224.

Brenner, Neil and Martin Aboleda (2017) Coda: Critical urban theory, reloded?. In: Brenner, Neil (ed.) Critique of Urbanization: Selected Essays. Berlin and Gütersloh: Bauverlag, 268-289.

Brenner, Neil and Christian Schmid (2017) Planetary urbanization. In: Brenner, Neil (ed.) Critique of Urbanization: Selected Essays. Berlin and Gütersloh: Bauverlag, 186-191.

Brenner, Neil and Daniel Ibañez (2017) The Agency of Design in an Age of Urbanization. In: Brenner, Neil (ed.) Critique of Urbanization: Selected Essays. Berlin and Gütersloh: Bauverlag, 224-236. 
Couser, G.Thomas (2012) Memoir: An Introduction. Oxford: Oxford University Press.

Davies, Norman and Roger Moorhouse (2003) Microcosm. Portrait of a Central European City. London: Random House.

De Certeau, Michel ([1984] 1988) The Practice of Everyday Life. Berkeley and Los Angeles: University of California Press.

Genette, Gérard ([1987]1997) Paratexts: Thresholds of Interpretation. Cambridge: Cambridge University Press.

Gleber, Anke (1999) The Art of Taking a Walk: Flanerie, Literature, and Film in Weimar Culture. Princeton, New Jersey: Princeton University Press.

Goodman, Ralph (2011) Ivan Vladislavić's Portrait with Keys: Fudging a book by its cover?”. In: Gaylard, Gerald (ed.) Marginal Spaces: Reading Ivan Vladislavić. Johannesburg: Wits University Press, $276-286$.

Goonewardena, Kanishka (2005) The urban sensorium: space, ideology and the aestheticization of politics. Antipode. A Radical Journal of Geography 37(1), 46-71.

Graham, James (2008) Ivan Vladislavić and the possible city. Journal of Postcolonial Writing 44 (4), 333-344.

Graham, James (2007) Exploding Johannesburg: Driving in a worldly city. Transtext(e)s. Transcultures: Journal of Global Cultural Studies 3, 67-83.

Graham, Shane (2006) Layers of permanence: Toward a spatial-materialist reading of Ivan Vladislavić's The Exploded View. Scrutiny 211 (2), 48-61.

Harvey, David (2014) Cities or Urbanization? In: Neil Brenner (ed.) Implosions/Explosions. Towards a Study of Planetary Urbanization. Berlin: jovis Verlag GmbH, 52-66.

Herbert, Caroline (2016) Postcolonial Cities. In: McNamara, Kevin R. (ed.) The Cambridge Companion to the City in Literature. Cambridge: Cambridge University Press, 200-215.

Hinchliffe, Steve (1996) Technology, power, and space - the means and ends of geographies of technology. Environment and Planning D: Society and Space 14, 659-682.

Howard, Jean E. (2007) Theatre of a City: The Places of London Comedy, 1598-1642. Philadelphia: University of Pennsylvania Press.

Jameson, Fredric ([1991] 1997) Postmodernism, or, The Cultural Logic of Late Capitalism. Durham: Duke University Press.

Jones, Megan (2011) Cars, capital and disorder in Ivan Vladislavić's The Eploded View and Portrait with Keys. Social Dynamics 37 (3), 379-393.

Lefebvre, Henri ([1970] 2003) The Urban Revolution. Minneapolis, London: University of Minnesota Press.

Lefebvre, Henri ([1974] 1991) The Production of Space. Oxford, Cambridge, Mass.: Blackwell.

Lehan, Richard (1998) The City in Literature: An Intellectual and Cultural History. Berkeley: University of California Press.

Lenta, Patrick (2009) Everyday abnormality: Crime and in/security in Ivan Vladislavić's Portrait with Keys. Journal of Commonwealth Literature 44 (1), 117-133.

Lynch, Kevin (1960) The Image of the City. Cambridge, Mass.: MIT.

Maier, Jessica (2015) Early Modern Maps of the Eternal City. Rome Measured and Imagined. Chicago and London: The University of Chicago Press.

Mannovich, Lev (2006) The poetics of augmented space. Visual Communication 5.2, 219-240.

Marais, Sue (2017) The economies of repetition: The market, the artistic, and the genocidal in Ivan Vladislavić's "Curiouser". The Journal of Commonwealth Literature 52(1), $27-41$.

Merrifield, Andy (2013) The Politics of the Encounter: Urban Theory and Protests Under PlanetaryUrbanization. Athens and London: The University of Georgia Press.

McLeod, John (2004) Postcolonial London: Rewriting the Metropolis. London and New York: Routledge.

Michel, Berit (2015) Mapping the City -Narrating 'Complexity': Urban Space in the Contemporary Anglophone Novel. Trier: WVT Wissenschaftlicher Verlag Trier. 
Mukherjee, Pablo (2012) Ivan Vladislavić: Traversing the uneven city. Journal of Postcolonial Writing 48 (5), 472-484.

Mumford, Lewis ([1961] 1979) The City in History. Harmondsworth: Penguin.

Newland, Paul (2008) The Cultural Construction of London's East End: Urban Iconography, Modernity and the Spatialisation of Englishness. Amsterdam and New York: Rodopi.

Nuttal, Sarah and Achille Mbembe (2007) Afropolis: From Johannesburg. PMLA 122(1), 280-288.

Pike, David L. (2005) Subterranean Cities. The World beneath Paris and London. Ithaca and London: Cornell University Press.

Ridley, Philip (2002) Introduction. In: Plays 1. London: Faber and Faber, vii-lx.

Seidel, Matt (2017) A view of South Africa: Ivan Vladislavic. Publisher's Weekly March 3.20 http:// www.publishersweekly.com/pw/by-topic/authors/profiles/article/73104-a-view-of-south-africaivan-vladislavic.html (Accessed on March 20, 2017).

Stow, John ([1603]1908) A Survey of London. Reprinted From the Text of 1603. Kingsford, C L (ed.) Oxford: Clarendon 1908. British History Online, http://www.british-history.ac.uk/no-series/survey-of-london-stow/1603 (Accessed on January 6, 2018)

Thrift, Nigel (2004) Driving in the city. Theory, Culture \& Society. London, Thousand Oaks and New Delhi: SAGE. 21 (4/5), 41-59.

Tinkler-Villani, Valeria (ed.) (2005) Babylon or New Jerusalem?: Perceptions of the City in Literature. Amsterdam and New York: Rodopi.

Vladislavić, Ivan ([2006] 2009) Portrait with Keys: The City of Johannesburg Unlocked. New York, London: Norton \& Co.

Vladislavić, Ivan (2004) The Exploded View. Johannesburg: Random House.

Vladislavić, Ivan ([2001] 2014) The Restless Supermarket. London and New York: And Other Stories.

Wachsmuth, David (2014) City as ideology: reconciling the explosion of the city form with tenacity of the City concept. Environment and Planning D: Society and Space 31, 75-90.

Walker, Richard (2015) Building a better theory of the urban. A response to 'Towards a new epistemology of the urban?'CITY 19 (2-3), 183-191.

Ewa KęBLowsKa- - awniczaK is Associate Professor of English Literature and Comparative Studies at the Department of English Studies, University of Wrocław (Poland). She is the author of The Visual Seen and Unseen: Insights into Tom Stoppard's Art. (2004) and From Concept-City to City Experience: A Study in Urban Drama (2013). Her current research interests include transdisciplinary examination of urbanism in new Anglophone literatures, visual culture studies, and uses of paratext in modern and contemporary drama in English.

Address: Prof. dr hab. Ewa Kębłowska-Ławniczak, Institute of English, Section of English Literature and Comparative Studies, Faculty of Letters, University of Wrocław, ul. Kuźnicza 22, 50-138 Wrocław, Poland. [email: ewa.keblowska-lawniczak@uwr.edu.pl] 
